\title{
New Perspectives on Transnational Public-Private Partnerships: A Critical Analysis of the United Nations-Business Partnership
}

\author{
MIN JOUNG PARK ${ }^{*}$ AND HANNAH JUN**
}

\begin{abstract}
This paper critically assesses the United Nations-business partnership since the establishment of the Sustainable Development Goals (SDGs) in 2015. This study provides a critical overview of relevant theoretical approaches, buttressed by evidence from public-private partnership cases. Applying international relations (IR) theories permits qualitative research on, and future evaluation of, the partnership's emergence. This study finds that while we see core elements of the rational choice perspective in the formation and implementation of the UN-business partnership, we see its legitimization via constructivist rhetoriceven for cases where the neo-Gramscian view is compelling. While traditional PPPs are often transnational, the mood articulated by the UN may have shifted goals for "private" parties, with firms' motivations moving from a purely for-profit stance to one that embraces more social responsibility; goals also shifted for "public" parties, from state to interstate objectives, and from micro (infrastructure) to macro (shared development goals) objectives.
\end{abstract}

Keywords: Corporate Social responsibility (CSR), International

Development, Post-2015 Development Agenda, Public-Private Partnership (PPP), United Nations

* Ph.D. Candidate, EwhaWomans University, Seoul, South Korea;

E-mail: mjparkfor@gmail.com

** Assistant Professor, EwhaWomans University, Seoul, South Korea;

E-mail: hannahjun@ewha.ac.kr

DOI: $10.16934 /$ isr.17.1.201606.37 


\section{INTRODUCTION}

The corporate social responsibility (CSR) discourse continues to galvanize civil society and the business sector in advanced economies, particularly in those where the Anglo-Saxon model of capitalism governs. While it remains a debated concept, corporate social responsibility has generally referred to corporate responsiveness to social agendas with regards to corporate behavior, and to performance in light of these responsibilities (Matten and Moon 2008). This can include a range of issues encompassing the environment (Dasgupta et al. 2001; Derwall et al. 2005; Henriques and Sadorsky 1999), society (Hillman and Keim 2001; Visser 2006, 2008), and governance (Bauer et al. 2004; Cremers and Nair 2005; Shleifer and Vishny 1997) that affect a variety of internal and external parties or stakeholders (Donaldson and Preston 1995; Freeman 1984). As a result, the promotion of more ethical business behavior has created a vibrant new industry, involving non-governmental organizations (NGOs), shareholder groups, and profit-making consultancies, among others.

One important dimension of this new development is the increasing emphasis placed by the United Nations (UN) on engaging the private sector in partnerships to achieve not only more socially responsible behavior but also the UN's development goals. As noted by Gregoratti (2013), we have seen the rationalization of such partnerships since as early as 1998 with the creation of the United Nations Fund for International Partnerships (UNFIP), the United Nations Development Programme's Global Sustainable Develop Facility, and ultimately the Global Compact (206). The formation in July 2003 of a high-level Commission under the aegis of the United Nations Development Program (UNDP) on the Private Sector and Development was, for the UN Secretary-General, “... yet another illustration of the rapidly growing partnership ... in our work to reach the Millennium Development Goals" (UN News Center 2003).

More recently, the corporate sector has been trying to engage more proactively in the process of setting up the post-2015 Sustainable Development Goals (SDGs), agreed upon by heads of states and governments at the UN Headquarters in September 2015. Strong business support for a linkage with the post-2015 agenda begs whether it means the birth of a new way of governance in the UN, in which non-state actors (particularly multinational corporations) co-govern along with state actors for the provision of new development goals. While the United Nations' activities concentrate on work in peace and security, these activities have significant impact on broader social and economic issues (Ruggie 2003, 317). Along this vein, the UN has made innovative efforts to achieve greater coherence through inclusion of networked organizational forms, such as the Global Compact, that go beyond the traditional intergovernmental mode and help to create a more inclusive and fluid global public domain (Ruggie 2003, 317).Ultimately, this reflects 
the fact that non-state actors have been increasingly engaged in authoritative decision-making (Hall and Biersteker 2002) in almost all policy areas, including in the field of development cooperation (Broadwater and Kaul 2005).

\section{TABle 1. COMPARISON OF THE United NATIONS' MiLlenNiUm DEVELOPMENT GoAlS (MDGs) AND SUSTAINABLE DEVELOPMENT GOALS (SDGS)}

\begin{tabular}{|c|c|c|}
\hline Theme & $\begin{array}{c}\text { UN Millennium } \\
\text { Development Goals (8) }\end{array}$ & $\begin{array}{c}\text { UN Sustainable } \\
\text { Development Goals (17) }\end{array}$ \\
\hline \multirow{3}{*}{$\begin{array}{l}\text { Hunger and } \\
\text { poverty }\end{array}$} & \multirow{3}{*}{$\begin{array}{l}\text { 1. Eradicate extreme hunger and } \\
\text { poverty }\end{array}$} & 1. No poverty \\
\hline & & 2. Zero hunger \\
\hline & & 3. Good health and well-being \\
\hline Education & 2. Achieve universal primary education & 4. Quality education \\
\hline Gender & $\begin{array}{l}\text { 3. Promote gender equality and } \\
\text { empower women }\end{array}$ & \multirow{4}{*}{ 5. Gender equality } \\
\hline \multirow{3}{*}{ Health } & 4. Reduce child mortality & \\
\hline & 5. Improve maternal health & \\
\hline & $\begin{array}{l}\text { 6. Combat HIV/AIDS, malaria and } \\
\text { other diseases }\end{array}$ & \\
\hline \multirow{5}{*}{ Environment } & \multirow{5}{*}{ 7. Ensure environmental sustainability } & 6. Clean water and sanitation \\
\hline & & 7. Affordable and clean energy \\
\hline & & 13. Climate action \\
\hline & & 14. Life below water \\
\hline & & 15. Life on land \\
\hline \multirow{6}{*}{$\begin{array}{l}\text { Economy and } \\
\text { society }\end{array}$} & \multirow{6}{*}{ (8. Global partnership for development) } & 8. Decent work and economic growth \\
\hline & & 9. Industry, innovation and infrastructure \\
\hline & & 10. Reduced inequalities \\
\hline & & 11. Sustainable cities and communities \\
\hline & & $\begin{array}{l}\text { 12. Responsible consumption and } \\
\text { production }\end{array}$ \\
\hline & & 16. Peace, justice and strong institutions \\
\hline Partnership & 8. Global partnership for development & 17. Partnership for the goals \\
\hline
\end{tabular}

SOURCE: adapted from the United Nations official website.

This paper aims to demonstrate that there is a lively debate on the partnership between the United Nations and the private sector. Specifically, this study conducts a critical assessment of the current state of the transnational public-private partnership (PPP) literature, arguing that some major international relations theories can be fruitfully applied to UN-business partnerships to conduct more theorybased comparative research. To investigate how the UN-business partnership has been rationalized and applied in literature and practice, this study first provides a background to UN-business partnerships and transnational PPPs. This is followed by a critical overview of theoretical approaches and findings concerning the emergence of the UN-business partnerships, which include the constructivist, neoGramscian, and rational choice perspectives. The analysis is buttressed by evidence via case studies and articulates shifts in transnational PPP goals and motivations. The paper then concludes with avenues for future research. 


\section{BACKGROUND TO UN-BUSINESS PARTNERSHIPS AND PUBLIC- PRIVATE PARTNERSHIPS}

With respect to the dynamic nature of UN-business partnerships, we have seen the corporate sector positioning itself in front of the post-2015 development framework. Business-led reports have emphasized the need for transformative change, and have put growth at the center of their vision for the post-2015 development agenda. Much of this activity has stemmed from prior corporate involvement in cooperation and shaping global agendas, including the UN Global Compact (Berliner and Prakash 2014) and the World Business Council for Sustainable Development (WBCSD). For example, Goal 1 of the Global Compact report proposes to "end poverty and increase prosperity via inclusive economic growth" (UN Global Compact 2013, 1), while the joint report of the Global Compact and the WBCSD notes that "it is recognized that development objectives cannot be achieved without economic growth."

The post-2015 agenda's involvement of business has influenced public discussion on goal setting. Instead of exercising indirect influence in setting up postMDGs, non-state actors have been directly involved in political steering and have attempted to co-govern along with state actors. Through the intergovernmental Open Working Group (OWG) on the Sustainable Development Goals (SDGs), the business community has been vocal in sharing perspectives on future UN global agendas.

In this sense, the renewed relationship between the UN and business can be regarded as a form of transnational PPP. In the literature, transnational publicprivate partnerships (PPPs) are understood as hybrid governance forms through which the political authority of non-state actors has been extended (Schäferhöff et al. 2009). Additionally, Börzel and Risse (2005) view transnational PPPs as "institutionalized cooperative relationships between public actors and private actors beyond the nation-state for governance purposes," and classify PPPs according to purpose and function as co-optation, delegation, and co-regulation. Simultaneously, the term "transnational public-private partnership" is not clear-cut, as the scope of transnational PPPs can be very diverse depending on the definition. To this end, Broadwater and Kaul (2005) conclude that there are at least 400 trans-national PPPs, compared to 50 in the 1980s, that address global challenges such as controlling communicable diseases or climate change, while Buse and Harmer (2007) restrict the private sector only to business and thus count 23 global health partnerships. Given confusion in the academic discourse on what constitutes transnational PPPs, we have seen few comparative or empirical studies conducted in the field.

For this study, we use the definition of transnational PPPs drawn from Schäferhöff et al. (2009), which defines PPPs as a formal agreement to deliver 
collective goods. Specifically, transnational PPPs represent "a hybrid type of governance, in which non-state actors co-govern along with state actors for the provision of collective goods, and adopt governance functions that have formerly been the sole authority of sovereign nation-states" (Schäferhöff et al. 2009, 455). The definition rejects the claim that PPPs have to be effective and successful in fulfilling the task and, unlike the World Bank's 2007 definition, excludes shared responsibilities from the definition as these are normative presumptions.

On the one hand, proponents consider PPPs a response to both state and market failure, suggesting that they improve the effectiveness and legitimacy of global governance (Schäferhöff et al. 2009). By responding to the mutual interests of state and non-state actors, PPPs can create win-win situations and succeed in the provision of collective goods through the pooling of resources, skills, and expertise (Reinicke et al. 2000). On the other hand, PPPs may be viewed as an example of the privatization and commercialization of world politics. For example, it can be argued that PPPs exhibit asymmetric power relations and mainly serve transnational corporations. Thus rather than promoting effective and legitimate global governance, PPPs may hinder sustainable development and deepen the North-South divide as the corporate sector is in a position to exert enormous impact on a state's policy priorities (Zammit 2003).

With regards to the academic discourse, conventional literature has suggested that research on transnational PPPs, especially regarding UN-business partnerships, is still at an infant stage. As such, there is a need for more empirical research to theorize the concept and its scope, as well as to clarify specific conditions for the emergence of such partnerships. Whilst largely theoretical, this study aims to highlight how the UN-business partnership has been rationalized and applied in both literature and practice. It draws on a review of publicly-available resources, including reports submitted via business-led processes. These include the UN Global Compact report, the joint report of the World Business Council for Sustainable Development (WBCSD), the Global Compact to the High-Level Panel (HLP), and the report to the Sustainable Development Solutions Network (SDSN) Thematic Group on business to the HLP. These initiatives are echoed by other reports, which originated from processes in which business actors have played an important role. To analyze methods of business engagement, this study employs a conceptual framework that includes constructivist, neo-Gramscian, and rational choice perspectives and incorporates case study evidence from recent UN-business partnerships.

\section{THEORETICAL PERSPECTIVES ON TRANSATIONAL PPPS: A COMPREHENSIVE REVIEW}

The emergence of the UN-business partnership can be examined from several 
theoretical perspectives within the discipline of international relations. This study examines UN-business partnerships via constructivist, neo-Gramscian, and rational choice perspectives. While the emergence of individual partnerships is often explained from a rationalist standpoint that depicts partners as rational self-interested agents, this paper aims to highlight a wider range of theoretical perspectives on the emergence of such partnerships. By doing so, this study attempts to analyze patterns of partnerships for sustainable development through the lens of three major theoretical schools, particularly as one perspective proves insufficient in explaining the current state of UN-business partnerships. By doing so, we should be able to assess how such partnerships have been rationalized and applied over time, thus clarifying and enriching the academic discourse.

\section{Constructivist Theories}

From a constructivist perspective, the evolution of the UN-business partnership is not simply a result of a rational response by self-interested actors to ensure more legitimate and effective cooperation. Rather, it is underpinned by "resource mobilization and the promotion of certain values and forms of governance ... for developmental and ethical goals" (Utting 2000, 3). These goals can include raising the profile of human rights, labor standards, and environmental issues, with related partnerships characterized by "complex multilateralism" (O'Brien 1997). Constructivist authors identify the emergence of a new "global public domain" (Schäferhöff et al. 2009, 455) as a normative structure that shapes actors' identities and interests (Kell and Ruggie 1999). Within this global public domain, the production of collective goods is no longer the responsibility of states alone, but is increasingly accomplished by NGOs and corporations that choose to respond to specific global issues. From the perspective of the UN, the rationale behind UN-business partnerships is that the UN alone can no longer handle global governance responsibilities due to its own identity crisis and the impact of globalization (Beausang 2003). We can argue that corporations control the process to some extent and consequently, corporations should be encouraged by the UN to undertake core business activities in a development-friendly way and help shape the international agenda (Nelson 2011).

In March 2009, a global corporate code of conduct on women's human rights developed through an international multi-stakeholder consultation process. The resulting Women's Empowerment Principles (WEPs) formed part of the UN Global Compact with business and civil society in March 2010. The WEPs aimed to create awareness about the collective economic benefits from gender equality by providing statistical evidence and enabling benchmarking that explicitly targets states and corporations. More in line with the constructivist perspective's focus on corporations promoting shared values through partnerships, the Principles were 
based on the mutual belief that promoting women's entrepreneurship and employment, especially in developing countries, would be helpful in achieving common development goals. Specifically, the Principles highlighted the situation of women employees across economic sectors and occupational hierarchies and involved high-level commitment from global chief executive officers (CEOs), whose signatures and declarations emphasizing economic gains from women's empowerment can be found on UN websites (Prügl and True 2014).

At a basic level, seven women's empowerment principles are associated with key indicators to monitor their impact and are fleshed out with specific programmatic action and best practice examples. Specifically, the Principles advocate: (1) leadership for gender equality; (2) equal opportunity, inclusion and non-discrimination; (3) health, safety and freedom from violence; (4) education and training; (5) empowering enterprise development, supply chain and marketing practices; (6) community leadership and engagement; and (7) transparency, measurement and reporting. In the case of the WEPs, partnerships do not simply solve a collective action problem or fill a governance gap as rationalists might suggest, but are part of a transnational transformation of governance and embedded in political struggles-an observation more consistent within a constructivist framework.

But beyond the question of whether transnational PPPs as evidenced by UNbusiness partnerships are actually motivated to engage in such partnerships primarily to promote specific values and global governance, some have argued that these partnerships fail to play a major role in the development of new global governance norms as they have been created unevenly across issues and have emerged in areas with some degree of regulatory institutionalization (Biermann et al. 2012). Even in the case of the WEPs, while the rhetoric behind the formation and implementation of the Principles intimated at broader governance and cooperation with women's empowerment issues, collective economic benefits (rather than common development goals) were also stressed.

In this regard, Biermann et al. (2012) note that we may be overly optimistic when it comes to the potential for partnerships to advance global sustainability governance, particularly as state and non-state actors excluded in such partnerships tend to consist of marginalized stakeholders. Constructivists have also highlighted that PPPs have become an increasingly diffusing institutional model and have argued for specific institutional designs towards a prevailing institutional form (Dingwerth and Pattberg 2009). With this in mind, we turn to neo-Gramscian approaches to understanding transnational partnerships.

\section{Neo-Gramscian Approach}

At the opposite end of the theoretical spectrum, the neo-Gramscian approach would assert that the $\mathrm{UN}$-business partnership is a political strategy through which 
business aims to secure corporate hegemony (Utting 2002). According to this perspective, the UN-business partnership emerges because corporations want to respond to pressure from the anti-globalization movement by proactively accommodating opposing claims. We may see this behavior come from an interest to stabilize the hegemonic capitalist worldview and support corporate-friendly global governance. Under the guise of the UN-business partnership, corporations can avoid changes in its core business while responding to civic activism in a self-interested way (Gramsci 1971). NGOs have also argued that while we already see strong corporate influence at the UN, the partnerships may ultimately contribute to partial privatization and commercialization of the UN system (TRAC 2000, 4). Simultaneously, marginalized groups are often excluded from discussions (Newell 2005), in-line with assertions from the constructivist view. We also see that power relationships between stakeholders shape the issues raised in partnerships (Prieto-Carrón et al. 2006, 984), with selective exclusion and inclusion suggesting complex power structures and political inequalities of such partnerships (Gregoratti 2013, 209).

\section{TABLE 2. United NATIONS Global COMPACT}

\begin{tabular}{ll}
\hline \multicolumn{1}{c}{ Category } & \multicolumn{1}{c}{ Principle } \\
\hline \multirow{3}{*}{ Human Rights } & $\begin{array}{l}\text { Principle 1: Businesses should support and respect the protection of } \\
\text { internationally proclaimed human rights; and }\end{array}$ \\
\cline { 2 - 2 } & Principle 2: Make sure that they are not complicit in human rights abuse \\
\hline \multirow{3}{*}{ Labour } & $\begin{array}{l}\text { Principle 3: Businesses should uphold the freedom of association and the } \\
\text { effective recognition of the right to collective bargaining; }\end{array}$ \\
\cline { 2 - 2 } & Principle 4: The elimination of all forms of forced and compulsory labour; \\
\cline { 2 - 2 } & Principle 5: The effective abolition of child labour; and \\
\cline { 2 - 2 } & $\begin{array}{l}\text { Principle 6: The elimination of discrimination in respect of employment } \\
\text { and occupation. }\end{array}$ \\
\hline \multirow{3}{*}{ Environment } & $\begin{array}{l}\text { Principle 7: Businesses should support a precautionary approach to } \\
\text { environmental challenges; }\end{array}$ \\
\cline { 2 - 2 } & $\begin{array}{l}\text { Principle 8: Undertake initiatives to promote greater environmental } \\
\text { responsibility; and }\end{array}$ \\
\cline { 2 - 2 } & $\begin{array}{l}\text { Principle 9: Encourage the development and diffusion of environmentally } \\
\text { friendly technologies. }\end{array}$ \\
\hline \multirow{2}{*}{ Anti-Corruption } & $\begin{array}{l}\text { Principle 10: Businesses should work against corruption in all its forms, } \\
\text { including extortion and bribery. }\end{array}$ \\
\hline
\end{tabular}

With regards to the institutional design of the UN Global Compact (UNGC), it is the first attempt by the UN to specifically address transnational companies (Rasche 2012, 34). The idea was introduced in a context of strong public antiglobalization sentiments, including violent street protests in Seattle, Prague, and Genoa. The UN Global Compact sponsors viewed the UNGC as a learning network rather than a compliance-based corporate social responsibility (CSR) standard. Specifically, it was regarded as a means to highlight "norm diffusion and the dissemination of practical know-how and tools" (Ruggie 2007, 820). The only 
commitment required by companies is a written statement of support from the company's chief executive officer and an annual, informal report on progress with work on the 10 principles (refer to Table 2). Given the emphasis on the learning network model, UNGC sponsors have sought to attract a large membership within which information sharing and social pressure could encourage firms to adopt CSR norms. At its core, the Global Compact contributes to giving the company a social license to operate, and is argued to be beneficial to companies' reputation management, brand image, employee satisfaction, recruitment, stakeholder relations, and customer satisfaction.

But given its norm-based emphasis, the Global Compact does not impose concrete outcome standards on participants. Some have accused it for allowing irresponsible firms to join, thus giving them a cover to hide their activities. In this way, the UN may be providing a cover for "corporate criminals" given the UN's positive image, such as the impression that the UN has officially endorsed genetically-engineered seeds and foods with the participation of Novartis and Aventis in the Global Compact (TRAC 2000, 7). In July 2004, 23 NGOs signed a statement criticizing the Compact for providing "little but a public relations cover for global corporate malefactors," and for lacking legally binding instruments, thus calling on the UN Secretary-General to "go beyond repositioning the Global Compact and instead to fundamentally re-design it as an instrument of real corporate accountability-or, alternatively, to disband it entirely" (Joint Civil Society Statement on the Global Compact and Corporate Accountability 2004).

Table 3. Spectrum of Theoretical Perspectives on Transnational PublicPRIVATE PARTNERSHIPS

\begin{tabular}{|c|c|c|c|}
\hline & $\begin{array}{l}\text { Constructive } \\
\text { Perspective }\end{array}$ & $\begin{array}{c}\text { Realist } \\
\text { Perspective }\end{array}$ & $\begin{array}{l}\text { Neo-Gramscian } \\
\text { Perspective }\end{array}$ \\
\hline $\begin{array}{l}\text { Rationale for } \\
\text { emergence of } \\
\text { transnational PPPs }\end{array}$ & $\begin{array}{l}\text { Partnerships as evidence } \\
\text { of resource mobilization } \\
\text { and the promotion of } \\
\text { values and governance } \\
\text { for developmental and } \\
\text { ethical goals }\end{array}$ & $\begin{array}{l}\text { Transnational PPPs } \\
\text { emerge primarily as a } \\
\text { result of the overlap } \\
\text { between public and } \\
\text { private actors' interests }\end{array}$ & $\begin{array}{l}\text { Partnerships represent a } \\
\text { political strategy through } \\
\text { which business aims to } \\
\text { secure corporate } \\
\text { hegemony }\end{array}$ \\
\hline Assumptions & $\begin{array}{l}\text { Social structures and } \\
\text { agents mutually co- } \\
\text { determined }\end{array}$ & $\begin{array}{l}\text { Incentive-based approach } \\
\text { utilized to solve a } \\
\text { collective action problem }\end{array}$ & $\begin{array}{l}\text { Selective exclusion/ } \\
\text { inclusion suggests } \\
\text { complex power } \\
\text { structures and political } \\
\text { inequalities of such } \\
\text { partnerships }\end{array}$ \\
\hline $\begin{array}{l}\text { Function of } \\
\text { Transnational } \\
\text { PPPs }\end{array}$ & $\begin{array}{l}\text { Value-oriented } \\
\text { (shared values and global } \\
\text { governance) }\end{array}$ & $\begin{array}{l}\text { Goal-oriented (primarily } \\
\text { economic) }\end{array}$ & $\begin{array}{l}\text { Power-oriented } \\
\text { (corporate interest focus) }\end{array}$ \\
\hline Example & $\begin{array}{l}\text { Women's Empowerment } \\
\text { Principles (WEPs) }\end{array}$ & $\begin{array}{l}\text { Global Alliance for } \\
\text { Vaccines and } \\
\text { Immunizations (GAVI) }\end{array}$ & $\begin{array}{l}\text { UN Global Compact } \\
\text { (UNGC) }\end{array}$ \\
\hline
\end{tabular}


Utting and Zammit (2009) further argued that although the UN has taken a lead in advocating PPPs, initiatives such as the UN Global Compact often lose objectivities by allowing other institutions and individuals to dominate their agendas. The neo-Gramscian view would argue that this would have to do with firms' selfinterest in legitimizing its actions under a veil of corporate social responsibility and ethical business. Furthermore, neo-Gramscians highlight that the UN-business partnership exemplifies the reinforcement of existing power structures, in contrast with constructivist hopes for transnational PPPs representing corporate participation in achieving shared values and global governance.

\section{Rational Choice Perspective}

Between the constructivist and neo-Gramscian views, the rational choice approach offers a compelling analysis of how the UN-business partnership emerged. At its core, it argues that the interests of public and private actors overlap, which is often a central condition for formulating partnerships. Concerning international organizations (IOs), the rational choice perspective argues that IOs have incentives to create public-private partnerships in order to reduce their dependence on member countries' subsidies. Since the European sovereign debt crisis, leading donors in Europe have significantly reduced their financial support. From this perspective, there is strong financial incentive to partner with capital-rich corporations. Moreover, international organizations such as the UN face highly technical issues for which they lack expertise, while business often has the technical know-how and resources necessary to tackle current development challenges (Tesner and Kell 2000). As such, the motivation for the UN to engage in such partnerships is clear.

On the firm side, it is also a rational choice for firms to create partnerships with the UN in order to obtain access to public tenders and subsidies. The "license to operate" in new markets is another incentive for business to participate, and corporations may also gain reputational benefits through public image improvement (UNIDO 2002). Additionally, governments also have incentives to engage in partnerships. Governments may gain greater control over policy formulation and implementation, and may get closer to attaining corporate expertise.

But while the rational choice explanation has been the conventional argument in PPP literature as it offers simple and compelling arguments, the interest or incentive-based approach has limitations in accounting for the divergence in institutional forms of PPPs (Witte and Reinicke 2005). Unlike the highly formalized World Trade Organization (WTO) sanctions, UN-business partnerships are based on a voluntary mechanism characterized by loose cooperation. So how can we understand this difference?

Over the past few decades, partnerships between various UN entities and the private sector have become conventional strategies for responding to global public 
health challenges (e.g., AIDS, tuberculosis, malaria) at both the national and international level. Through these PPPs, multi-stakeholders have combined skills, expertise, and resources to implement programs at a much larger scope than what could have been possible for each individual organization working separately. In particular, this subset of PPPs that specifically focuses on product development for vaccines and other drugs has been termed "product development partnerships," or PDPs (Smith, 2009). Such a partnership would not only utilize the technological expertise of private firms, but it would funnel those resources and streamline objectives so that they are consistent with the UN's overarching Millennium and Sustainable Development Goals.

One example of such a PPP is the Global Alliance for Vaccines and Immunizations (GAVI). GAVI was established in 2000 at the World Economic Forum as a partnership between multiple agencies in the UN, such as the World Health Organization (WHO), UNICEF (The United Nations Children's Fund), the private sector (e.g., Bill an Melinda Gates Foundation), the International Federation of Pharmaceutical Manufacturers Associations (IFPMA), as well as donor governments that include the United States, United Kingdom, and the Netherlands. The roots of GAVI can be found in the Children's Vaccine Initiative (CVI), which was regarded as having performed inadequately due to a lack of leadership, autonomy, and financial resources, unclear mission and targets, and limited collaboration with the private sector (Muraskin 2002).

At the outset, GAVI was conceived with the recognition that the increasingly complex vaccine development and immunization process required partnerships, and that when GAVI was established, "things had matured to the point that no single organization ... could do it all" (Muraskin 2002, 145). In this sense, the rationalist view's emphasis on partnerships as a result of overlapping interest and resource complementarities via such partnerships proves convincing with GAVI's case. And although GAVI has been criticized in terms of authority and accountability, it has been regarded as "extremely successful" in increasing global awareness of vaccines and immunizations, consolidating markets to decrease costs, and generating resources from the partnerships (Martin and Halachmi 2012).

\section{Discussion on Theoretical Perspectives}

While rationalist theories are goal-oriented and take the actor's self-interest as a vantage point, we see some limitations with this perspective. For one, there are significant restrictions on an individual's capacity to adjust costs and benefits, not to mention individual ability to act upon what is deemed reasonable. For example, Simon (1955) argues that there are limits to the rationality of people, who are also emotional and often irrational, and this can be reflected in individual actions.

We can argue that the limits to rationality not only apply to individuals but 
also to organizations and institutions. In the field of international relations, actorrationality has been widely assumed in the so-called realist theories, which presume that power-maximizing states are the ultimate actors in world politics. But along the same vein, one could argue that state actors are also restricted in maximizing their interests by other factors. Unlike the rational choice perspective, which is based on methodological individualism according to which the "elementary unit of social life is the individual human action" (Elster 1989, 13), constructivist perspectives argue that social structures and agents are mutually co-determined, with international regimes and institutions constituting the central way to understand international affairs.

At least for the case studies utilized in this study, we have seen core elements of the rational choice perspective in the formation and implementation of Women's Empowerment Principles, UN Global Compact, and the Global Alliance for Vaccines and Immunizations. Simultaneously, we see the applicability of other theoretical perspectives underpinning those partnerships. For example, an optimistic view of the WEPs can be seen within a constructivist context of corporate participation to further development goals and contribute to better global governance. Seen from this perspective, we may ask whether this represents corporate attempts to justify rationalist views with constructivist language for legitimization purposes, or a hybrid of the two perspectives in understanding which issues come to the forefront in transnational PPPs.

Even in the case of the UN Global Compact, which has been viewed with cynicism by those adhering to a neo-Gramscian perspective, it is clear that corporations feel compelled to use rhetoric that aligns more with constructivist and rationalist views. But as highlighted by the neo-Gramscian view, transnational PPPs are prone to exclude marginalized actors and can be viewed as serving primarily corporate interests. If the international development community is to rely on partnerships to bring about structural change and long-term development impacts, the theoretical discussion indicates that there is a need for greater transparency and more accountable business engagement in UN processes (Pingeot 2014).

\section{SHIFTS IN GOALS AND MOTIVATIONS FOR UN-BUSINESS PARTNERSHIPS}

As demonstrated in the previous section, the constructivist, neo-Gramscian, and rational choice perspectives offer meaningful insights in understanding the emergence of some transnational PPPs (and in particular, the UN-business partnership). Even from the limited case studies highlighted in the analysis, we have been able to articulate key motivations, goals, and justifications for public and private involvement in these partnerships. 
On the private side, the traditional motivation for engaging in PPPs has been primarily profit-driven. This would be consistent with the rational choice perspective that argues for corporate involvement if the price is right. But as we view PPPs within a constructivist and particularly neo-Gramscian framework (not to mention corporate rhetoric with regards to the UN Global Compact and World Business Council for Sustainable Development), PPP participation goes beyond pure economic benefit and takes into greater consideration a corporation's broader social responsibilities. It remains doubtful whether corporations would still engage in PPPs if the project in question is economically unviable. But the additional theoretical perspectives may suggest that if two projects are equally lucrative from an economic standpoint, corporations may be inclined to choose the one in which the firm's social responsibilities may be better addressed.

On the public side, the traditional model has seen states primarily driving PPP involvement. Understandably, projects have tended to center on the provision of basic infrastructure that had otherwise not been provided. With the growing role of the United Nations in both articulating global development goals and engaging in partnerships (in-line with the UN's Millennium Development Goals and Sustainable Development Goals), we have seen a shift from a state-driven focus on infrastructure to more interstate participation and a broadening of issues to include sustainable development. This can be explained not only from the rational choice perspective, which argues that it would be in the rational interest of the UN to cooperate in PPPs due to the availability of corporate capital, but also from constructivist (e.g., Women's Empowerment Principles) and neo-Gramscian views.

TABLE 4. SHIFTING Motivations AND GOALS BEHIND TRANSNATIONAL PUBLICPRIVATE PARTNERSHIPS

\begin{tabular}{cll}
\hline Dimension & \multicolumn{1}{c}{ Traditional } & \multicolumn{1}{c}{ Current } \\
\hline \multirow{2}{*}{ Public } & $\begin{array}{l}\text { State-driven } \\
\text { Focus on basic infrastructure }\end{array}$ & $\begin{array}{l}\text { Interstate participation } \\
\text { Broadening to include sustainable development }\end{array}$ \\
\hline Private & Primarily profit-driven & $\begin{array}{l}\text { Driven by considerations of corporate social } \\
\text { responsibility }\end{array}$ \\
\hline
\end{tabular}

\section{CONCLUDING REMARKS}

This study presented an overview of the renewed UN-business partnership, focusing on its aspects as a transnational PPP. Although there is no clear cut definition of transnational PPPs, this paper argued that the UN-business partnership can be regarded as one since it is based on continuous, institutionalized transboundary interaction between public and private actors (Nelson 2002) and strives for the provision of collective goods (Utting 2002). The SDGs have been effectively formulated and constitute a large number of initiatives driven by multiple 
stakeholders, including business, although we do see side effects due to its voluntary nature.

The review concretized the application of international relations theories in understanding the emergence and motivations of the UN-business partnership, namely the rational choice, constructivist, and neo-Gramscian approaches. At least for the case studies utilized in this study, core elements of the rational choice perspective were seen in the formation and implementation of Women's Empowerment Principles, the UN Global Compact, and the Global Alliance for Vaccines and Immunizations. Simultaneously, we also highlighted the applicability of other theoretical perspectives underpinning those partnerships, particularly with respect to how partnerships are rationalized and legitimized in practice.

The diversity of theoretical perspectives and applications reflects the current state of knowledge on the emergence of transnational public-private partnerships. And while we have seen a lively theoretical discussion on the emergence of the UN-business partnership, there has been little research focusing on the linkages between theory and actual performance of PPPs, particularly within the framework of the UN's goal of pursuing effective partnerships for development. This would prove to be a meaningful area of research going forward. In addition, while it is clear that transnational PPPs, including the UN-business partnership, do not constitute a magic bullet for closing the participation gap of world development, future studies may engage in more context-specific research on different institutional mechanisms of transnational PPPs to improve both PPP performance and evaluation.

\section{REFERENCES}

Bauer, Rob, Nadja Gunster, and Roger Otten. 2004. "Empirical Evidence on Corporate Governance in Europe." Journal of Asset Management 5(2): 91-104.

Beausang, Francesca. 2003. "Is There a Development Case for United NationsBusiness Partnership?" LSE DESTIN Working Paper Series, London: LSE.

Berliner, Daniel and Aseem Prakash. 2014. "The United Nations Global Compact: An Institutionalist Perspective." Journal of Business Ethics 122(2): 217-223.

Börzel, Tanja A. and Thomas Risse. 2005. "Public-Private Partnerships: Effective and legitimate tools of international governance." In Complex Sovereignty: On the Reconstitution of Political Authority in the 21st Century edited by Edgar Grande Louis W. Pauly, 195-215. Toronto: University of Toronto Press. Broadwater, Ian and Inge Kaul. 2005. "Global Public-Private Partnerships: The Current Landscape.” A UNDP/ODS Background paper. UNDP: New York.

Buse, Kent and Andrew M. Harmer. 2007. "Seven Habits of Highly Effective Global Public-Private Health Partnerships: Practice and Potential." Social Science and Medicine 64: 259-271. 
Cerny, Philip G. 1999. "Globalization, Governance and Complexity." In Globalization and Governance, edited by Jeffrey A. Hart and Aseem Prakash. London: Routledge.

Cremers, Martijn and Vinay Nair. 2005. "Governance Mechanisms and Equity Prices." Journal of Finance 60(6): 2859-2894.

Dasgupta, Susmita and Benoit Laplanteand Nlandu Mamingi. 2001. "Pollution and Capital Markets in Developing Countries." Journal of Environmental Economics and Management 42: 310-335.

De Brujin, Johan A. and Arthur B. Ringeling. 1997. "Normative Notes: Perspectives on Networks." In Managing Complex Networks, edited by Walter J.M. Kickert, Erik-Hans Klijn and Johannes Franciscus and Maria Koppenjan. London: Sage.

Derwall, Jeroen, Nadja Gunster, Rob Bauer, and Kees Koedijk. 2005. "The EcoEfficiency Premium Puzzle.” Financial Analyst Journal 61(2): 51-63.

Dingwerth, Klaus and Philipp Pattberg. 2009. "World Politics and Organizational Fields: The Case of Transnational Sustainability Governance." European Journal of International Relations 15: 707-744.

Donaldson, Thomas and Lee Preston. 1995. "The Stakeholder Theory of the Corporation: Concepts, Evidence, and Implications." The Academy of Management Review 20(1): 65-91.

Elster, Jon. 1989. Nuts and Bolts for the Social Sciences. Cambridge: Cambridge University Press.

Freeman, R. Edward. 1984. Strategic Management: A Stakeholder Approach. Boston: Pitman.

Gramsci, Antonio. 1971. Selection from the Prison Notebooks. New York: International Publisher.

Gregoratii, Catia. 2013. "Growing Sustainable Business in Eastern Africa: The Potential and Limits of Partnerships for Development," Ch. 8. In Corporate Social Responsibility and Regulatory Governance: Towards Inclusive Development? edited by José Carlos Marques and Peter Utting. Basingstoke: Palgrave Macmillian.

Hall, Rodney B. and Thomas J. Biersteker. 2002. "The Emergence of Private Authority in the International System." In The Emergence of Private Authority in Global Governance edited by Rodney B. Hall and Thomas J. Bierteker. Cambridge: Cambridge University Press.

Hartman, Cathy L. and Edwin R. Stafford. 1997. "Green Alliances: Building New Business with Environmental Groups." Long Range Planning 30(2): 184-196.

Hartman, Cathy L., Peter S. Hofman, and Edwin R. Stafford. 1999. "Partnerships: A Path to Sustainability." Business Strategy and the Environment 8(5): 255-266. Henriques, Irene and Perry Sadorsky. 1996. "The Determinants of an Environmentally Responsive Firm: An Empirical Approach." Journal of Environmental 
Economics and Management 30: 381-395.

Hillman, Amy and Gerald Keim. 2001. "Shareholder Value, Stakeholder Management, and Social Issues: What's the Bottom Line?" Strategic Management Journal 22: 125-139.

Joint Civil Society Statement on the Global Compact and Corporate Accountability. 2004, assessed March 25, 2016, https://www.earthrights.org/campaigns/jointcivil-society-statement-global-compact-and-corporate-accountability.

Juniper, Christopher and Maggie Moore. 2002. "Synergies and Best Practices of Corporate Partnership for Sustainability." Corporate Environmental Strategy 9(3): 267-276.

Kell, Georg and John Gerard Ruggie. 1999. "Global Markets and Social Legitimacy: The Case of the Global Compact." Transnational Corporations 8: 101120.

Martin, Marie H. and Arie Halachmi. 2012. "Public-Private Partnerships in Global Health: Addressing Issues of Public Accountability," Risk Management and Governance. Public Administration Quarterly 36(2): 189-237.

Matten, Dirk and Jeremy Moon. 2008. “'Implicit' and 'Explicit' CSR: A Conceptual Framework for a Comparative Understanding of Corporate Social Responsibility." Academy of Management Review 33: 404-424.

Muraskin, William. 2002. "The Last Years of the CVI and the Birth of the GAVI." In Public Private Partnerships for Public Health, edited by Michael R. Reich. Cambridge: Harvard Center for Population and Development Studies. Nelson, Jane. 2002. Building Partnerships: Cooperation Between the United Nations System and the Private Sector. New York: United Nations Global Compact.

Newell, Peter. 2005. "Citizenship, Accountability and Community: The Limits of the CSR Agenda." International Affairs 81(3): 541-57.

OECD DAC Homepage. www.oecd.org/dac/states

Pingeot, Lou. 2014. Corporate Influence in the Post-2015 Process. New York: Global Policy Forum.

Prieto-Carrón, Marina, Peter Lund-Thomsen, Anita Chan, Anna Muro, and Bushanan Chandra. 2006. "Critical Perspectives on CSR and Development: What We Know, We Don't Know and What We Need to Know." International Affairs 82(5): 977-87.

Prügl, Elisabeth and Jacquie True. 2014. "Equality Means Business? Governing Gender Through Transnational Public-Private Partnerships.” Review of International Political Economy 21(6): 1137-1169.

Quintos, Paul L. 2014. "The Post-2015 Corporate Development Agenda," accessed, https://www.beta4.onintenational.org.

Rasche, Andreas. 2012. "The United Nations and Transnational Corporations: How the UN Global Compact Has Changed the Debate." In Globally Responsible Leadership: Business According to the UN Global Compact edited by Joanne 
T. Lawrence and Paul W. Beamish. Thousand Oaks: Sage.

Reinicke, Wolfgang, Francis Deng, Jan Martin Witte, Thorsten Benner, Beth Whitaker, and John Gershman. 2000. Critical Choices: The United Nations Networks, and the Future of Global Governance. Ottawa: International Development Research Center.

Ruggie, John Gerard. 2003. "The United Nations and Globalization: Patterns and Limits of Institutional Adaptation." Global Governance 9: 301-321.

Ruggie, John Gerard. 2007. "Business and Human Rights: The Evolving International Agenda." American Journal of International Law 101(4): 819-840.

Schäferhöff, Marco, Sabine Campe, and Christopher Kaan. 2009. "Transnational Public-Private Partnerships in International Relations: Making Sense of Concepts, Research Frameworks, and Results.” International Studies Review 11: 451-474.

Shleifer, Andrei and Robert Vishny. 1997. "A Survey of Corporate Governance." Journal of Finance 52: 737-783.

Smith, James. 2009. "Public-Private Partnerships and HIV Vaccine Research." HIV Therapy 3(4): 345-349.

Sustainable Development Solutions Network. 2013. An Action Agenda for Sustainable Development: Report for the UN Secretary-General, 6 June 2013. New York: UN.

Tesner, Sandrine and Georg Kell. 2000. The United Nations and Business. New York: Macmillan.

The Guardian. "UN Opens for Business: The Sustainable Development Goals Fund Explained," accessed June 18, 2015, http://www.theguardian.com/sustain able-business/2015/jan/28/un-business-sustainable-development-goals-fundmillenium.

TRAC. 2000. "Tangled Up in Blue: Corporate Partnerships at the United Nations." accessed www.corpwatch.org.

UN Global Compact. 2013. Corporate Sustainability and the United Nations Post2015 Development Agenda: Perspectives from UN Global Compact Participants on Global Priorities and How to Engage Business Towards Sustainable Development Goals. Geneva: UN Global Compact.

UN Global Compact. 2014. The Role of Business and Finance in Supporting the Post-2015 Agenda, accessed June 10, 2015, https:/www.unglobalcompact. org/docs/news_9.6/Post2015_WhitePaper_2July14.pdf.

UN Global Compact LEAD. 2011. Catalyzing Transformational Partnerships Between the United Nations and Business. Geneva: UN Global Compact.

UN Global Compact and World Business Council for Sustainable Development. 2013. Joint Report to the High-Level Panel of the Post-2015 UN Development Agenda. Geneva: UN Global Compact.

UNIDO. 2002. Corporate Social Responsibility: Implications for Small and Medi- 
um Enterprises in Developing Countries. Vienna: UNIDO.

UN News Center. 2003. "Annan Launches New UN-Private Alliance to Fight Poverty, AIDS, Illiteracy,” July 25 2003, accessed June 15, 2015, http://www.un.org/ apps/news/story.asp?NewsID $=7834 \& \mathrm{Cr}=$ millennium $\& \mathrm{Cr} 1=$ goals.

UN Secretary-General. 2002. United Nations Fund for International Partnerships. UN Doc. A/53/133. New York: UN.

Utting, Peter. 2000. "UN-Business Partnerships: Whose Agenda Counts?" Presented at seminar on Partnerships for Development or Privatization of the Multilateral System? Oslo. December 2000.

Utting, Peter. 2002. Regulating Business via Multistakeholder Initiatives: A Preliminary Assessment. In Voluntary Approach to Corporate Social Responsibility: Readings and a Resource Guide. Geneva: UNRISD (United Nations Research Institute of Social Development).

Visser, Wayne. 2006. "Revisiting Carroll's CSR Pyramid: An African Perspective." In Corporate Citizenship in Developing Countries edited by Esben Rahbek Pedersen and Mahad Huniche. Copenhagen: The Copenhagen Centre.

Visser, Wayne. 2008. "Corporate Social Responsibility in Developing Countries." In The Oxford Handbook of Corporate Social Responsibility edited by Andrew Crane, Dirk Matten, Abagail McWilliams, Jeremy Moon and Donald S. Siegel. Oxford: Oxford University Press.

Witte, Jan Martin and Wolfgang H. Reinicke. 2005. Business Unusual: Facilitating United Nations Reform through Partnerships. New York: UN Global Compact. World Bank. 2014. Public-Private Partnerships Reference Guide Version 2.0. Washington: World Bank.

World Business Council for Sustainable Development. 2012. Changing Pace: Public Policy Options to Scale and Accelerate Business Action towards Vision 2050. Geneva: WBCSD. 